\title{
1 Carbon leakage, relocation, and halo
}

\author{
A framework to understand \\ impacts of China's carbon- \\ energy policy on Asia's energy \\ transitions
}

Akihisa Mori

\section{The Paris Agreement and Asia}

In 2015, 195 countries and the European Union (EU) signed the Paris Agreement under the United Nations Framework for Climate Change Convention (UNFCC). The agreement aims to strengthen the global response to the threat of climate change by limiting the global temperature rise in this century to below $2^{\circ} \mathrm{C}$, above pre-industrial levels, and endeavoring to limit the temperature increase even further to $1.5^{\circ} \mathrm{C}$ (UNFCCC, 2015). This goal requires all Parties to submit nationally determined contributions (NDCs), report their emission and efforts regularly, and update them every five years.

In response, 186 countries submitted their first NDCs by September 2020 (UNFCCC, 2020), but only some submitted their updates. Except for Brunei and the Philippines, all the countries in Northeast, Southeast, and South Asia submitted their NDCs (Table 1.1). Although full implementation of unconditional NDCs is estimated to result in a 15 gigaton gap in $\mathrm{CO}_{2}$ emissions $\left(\mathrm{GtCO}_{2} \mathrm{e}\right)$ by 2030 compared with the $2^{\circ} \mathrm{C}$ scenario, and a global mean temperature rise of $3.2^{\circ} \mathrm{C}$ by 2100 (UNEP, 2019), the step is an advancement toward reducing greenhouse gas $(\mathrm{GHG})$ emissions.

In its NDC, China committed to achieving peak carbon dioxide $\left(\mathrm{CO}_{2}\right)$ in approximately 2030 and to an endeavor to peak early and reduce $\mathrm{CO}_{2}$ per unit of GDP or carbon intensity by $60 \%-65 \%$ from the 2005 level. To achieve the targets, the government committed to an increase of approximately $20 \%$ in the share of non-fossil fuels in primary energy consumption, and an increase of approximately 4.5 billion cubic meters in the forest stock volume compared with the 2005 level (NDRC, 2015). However, these commitments can raise the long-standing concerns of energy security and the cost of climate change measures decreasing economic growth.

To prevent climate policy from restricting economic growth, the government reframed climate change prevention as part of development (NDRC, 2007) and clean energies as new growth points (Chen, 2013). It fostered renewable and nuclear power industries and energy efficiency as a means of

DOI: $10.4324 / 9781003190905-2$ 
Table 1.1 Nationally determined contributions (NDCs) in selected Asian countries

\begin{tabular}{|c|c|c|c|c|c|}
\hline $\begin{array}{l}\text { Unconditional } \\
\text { contribution } \\
\text { target }\end{array}$ & $\begin{array}{l}\text { Conditional } \\
\text { contribution } \\
\text { target } \\
\text { (international } \\
\text { support) }\end{array}$ & $\begin{array}{l}\text { Year of } \\
\text { achievement }\end{array}$ & Metrics & $\begin{array}{l}\text { Base } \\
\text { year }\end{array}$ & $\begin{array}{l}\text { Year of } \\
\text { submission }\end{array}$ \\
\hline
\end{tabular}

Northeast Asia

\begin{tabular}{|c|c|c|c|c|c|c|}
\hline China & $60 \%-65 \%$ & - & 2030 & Intensity & 2005 & 2016 \\
\hline Japan & $25 \%$ & - & 2030 & Absolute & 2005 & 2016/ \\
\hline South Korea & $37 \%$ & - & 2030 & $\begin{array}{l}\text { BAU } \\
\text { scenario }\end{array}$ & 2020 & 2016 \\
\hline Taiwan & & - & 2030 & $\begin{array}{l}\text { BAU } \\
\quad \text { scenario }\end{array}$ & & - \\
\hline Mongolia & $14 \%$ & - & 2030 & $\begin{array}{l}\text { BAU } \\
\text { scenario }\end{array}$ & 2030 & 2016 \\
\hline \multicolumn{7}{|l|}{ Southeast Asia } \\
\hline Cambodia & $27 \%$ & & 2030 & $\begin{array}{l}\text { BAU } \\
\text { scenario }\end{array}$ & & 2017 \\
\hline Indonesia & $29 \%$ & $41 \%$ & 2030 & $\begin{array}{l}\text { BAU } \\
\text { scenario }\end{array}$ & 2010 & 2016 \\
\hline Malaysia & $35 \%$ & $45 \%$ & 2030 & Intensity & 2005 & 2016 \\
\hline Singapore & $36 \%$ & - & 2030 & Intensity & 2005 & 2016/ \\
\hline Thailand & $20 \%$ & $25 \%$ & 2030 & $\begin{array}{l}\text { BAU } \\
\text { scenario }\end{array}$ & 2005 & 2016 \\
\hline Vietnam & $9 \%$ & $27 \%$ & 2030 & $\begin{array}{l}\text { BAU } \\
\text { scenario }\end{array}$ & 2014 & 2016/ \\
\hline \multicolumn{7}{|l|}{ South Asia } \\
\hline Bangladesh & $5 \%$ & $15 \%$ & 2030 & $\begin{array}{l}\text { BAU } \\
\text { scenario }\end{array}$ & & 2016 \\
\hline India & $33 \%-35 \%$ & & 2030 & Intensity & 2005 & 2016 \\
\hline Pakistan & - & $20 \%$ & 2030 & $\begin{array}{l}\text { BAU } \\
\text { scenario }\end{array}$ & & 2016 \\
\hline Sri Lanka & $3 \%$ & $7 \%$ & 2030 & $\begin{array}{l}\text { BAU } \\
\quad \text { scenario }\end{array}$ & 2010 & 2016 \\
\hline
\end{tabular}

Note: As of September 2020.

Source: The author's compilation based on UNFCCC (2020) and Industrial Energy Saving and Carbon Reduction Information Web, Taiwan (n.a).

safeguarding energy security. The government mandated large power generators to supply renewable energy-sourced electrcity (RES=E), and annually increased its ratio to the total power supply. Additionally, it implemented various preferential measures to foster renewable-energy manufacturers (de la Tour et al., 2011; Horii, 2014) and expanded the scope of the feed-in tariff (FiT) to solar photovoltaic (PV) to rescue their manufacturers from the adverse impacts of the anti-dumping measures by the EU and the United States. The government also initiated local carbon emission trading pilots in four 
provinces and five cities to advance the nationwide emission trading scheme, and low-carbon development pilots in 42 provinces and cities. After the government implemented these measures, in the 13th Five-Year Plan for Energy (2016-2020), it set mandatory targets, for example, to reduce carbon intensity by $18 \%$ of the 2015 level and increase the installation capacity of wind and solar power by $210-250$ and $110-150 \mathrm{GW}$, respectively.

The sudden increase in wind and solar power in the domestic market intensified the contestation with incumbent coal power generators, resulting in substantial wind and solar curtailment in the first half of the 2010s (Mori, 2018). In addition, rising health concerns over China's worsening air pollution, represented by Chai Jing's 104-minute documentary Under the Dome (2015), provided opportunities to transform consumer behavior and government policy (Koehn, 2016). The government responded to the pressures to implement administrative order and regulations on coal power and heating plants, including consolidation of small and obsolete plants, mandates to employ technologies that are more efficient, and installation of fuel-gas desulfurization. It also prompted State Grid to invest in long-distance ultra-voltage transmission lines to mitigate the renewable curtailment and increased consumption of wind and solar power.

These stringent regulations on coal power and complementary measures to increase RES-E have increased the installed capacity of wind and solar PV and their power generation (Figures 1.1a and 1.1b) and decreased the potential new coal power opportunities within China.

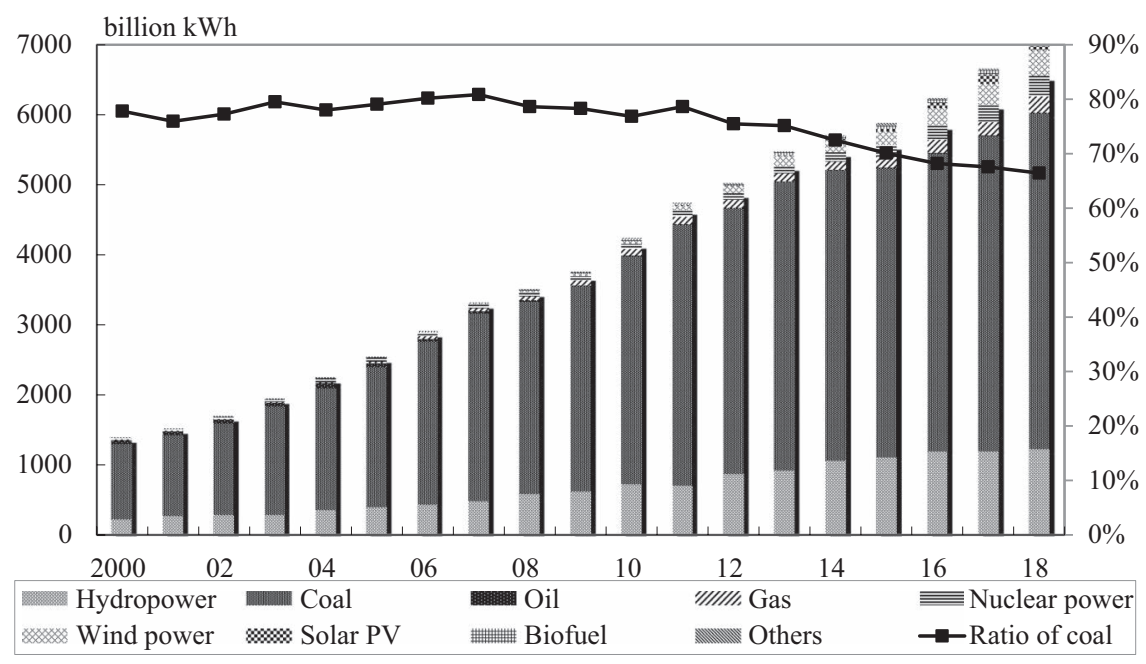

Figure 1.1a Energy mix in power generation in China in 2000-2018.

Source: The author's compilation based on IEA (2020). 


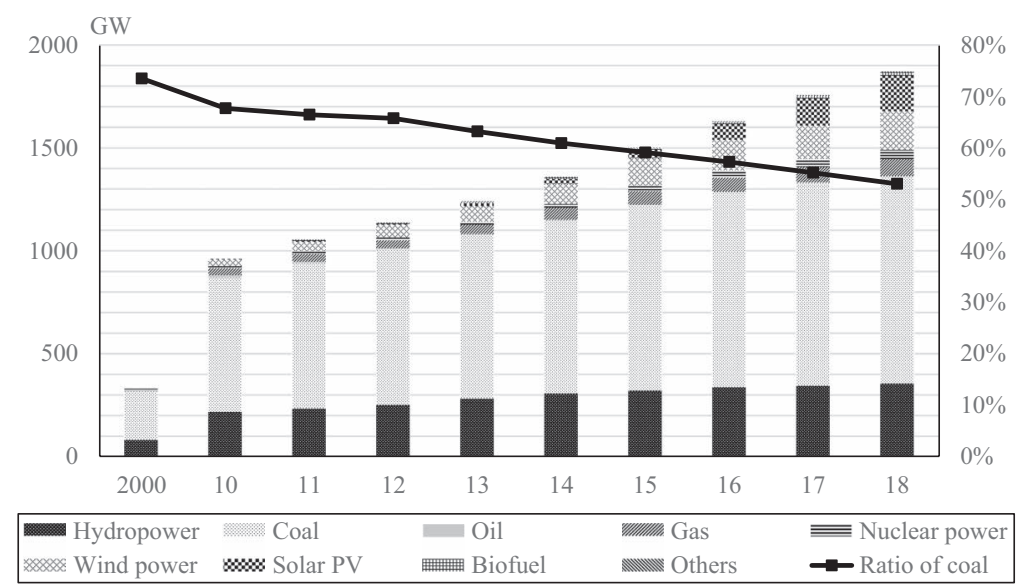

Figure $1.1 b$ Energy mix in installed power generation capacity in China in 2000-2018.

Note: Data for the years 2001-2009 is available only for thermal power as a whole.

Source: The author's compilation based on China Electricity Power Statistical Yearbook, each year.

\section{Implications to China-Asia energy relation}

The decreased opportunity for new coal power projects and fierce competition over RES-E have motivated the Chinese power industry-including existing power companies, emerging RES-E producers, manufacturers, and developers (engineering and construction companies) - to seek business opportunities in foreign countries. ${ }^{1}$ On this temporal occasion, the Chinese government has accelerated its "going global" strategy and Belt and Road Initiative (BRI), which direct them toward foreign projects (Mori and Takehara, 2018).

China had already started overseas official finance in the resource extraction sector to secure energy that was indispensable for sustaining economic growth. In the mid-2000s, it reframed energy security to recognize that additional development of oil and gas worldwide would enhance the energy security of China through increasing global energy security (Hayashi, 2006). In this recognition, China expanded the scope of overseas finance to infrastructure projects necessary for mining and transporting resources to China, and then Chinese company-initiated projects, including new installed capacity (greenfield investment) in the electricity sector (Hervé-Mignucci and Wang, 2015). To reduce country and commercial risks, the country employed the resource-financed infrastructure in which host country governments pledge their interest in some or all of the 
revenue flows it will receive from the resource production project to a lender (Beardsworth and Schmidt, 2014). In addition, the Chinese government set up bilateral and regional development funds to finance investments in connectivity infrastructure as a part of the BRI. These funds amounted to US\$164.4 billion, of which the Silk Road Fund accounted for the largest contributors (Gallagher et al., 2018). Fossil fuel investments accounted for $91 \%$ of energy-sector syndicated loans by the six major Chinese banks and $61 \%$ of energy-sector loans financed entirely by state-backed China Development Bank or Export-Import Bank of China between 2014 and 2017 (Lechner et al., 2020).

Finance and investments can satisfy increasing electricity demand in developing countries, helping them increase access to affordable, reliable modern energy, overcome power shortages, and sustain economic growth at a lower cost. In particular, developing countries with power shortages that could easily access cheap coal accepted China's finance and investments in the 2000s. Indonesia's ratio of coal power increased from $24 \%$ in 1995 to $36 \%$ in 2000 , and to $56 \%$ in 2015 . Vietnam's ratio also increased from $12 \%$ in 2000 to $30 \%$ in 2015 , despite a temporal decline in 2006-2009 due to the completion of large-scale hydropower (Figure 1.2). This finance and investments go beyond coal-rich countries to arrive at coal-poor small countries, such as Cambodia, Laos, and Uzbekistan, after the global financial crisis in 2008-2009; the crisis sharply reduced the appetite of commercial banks for

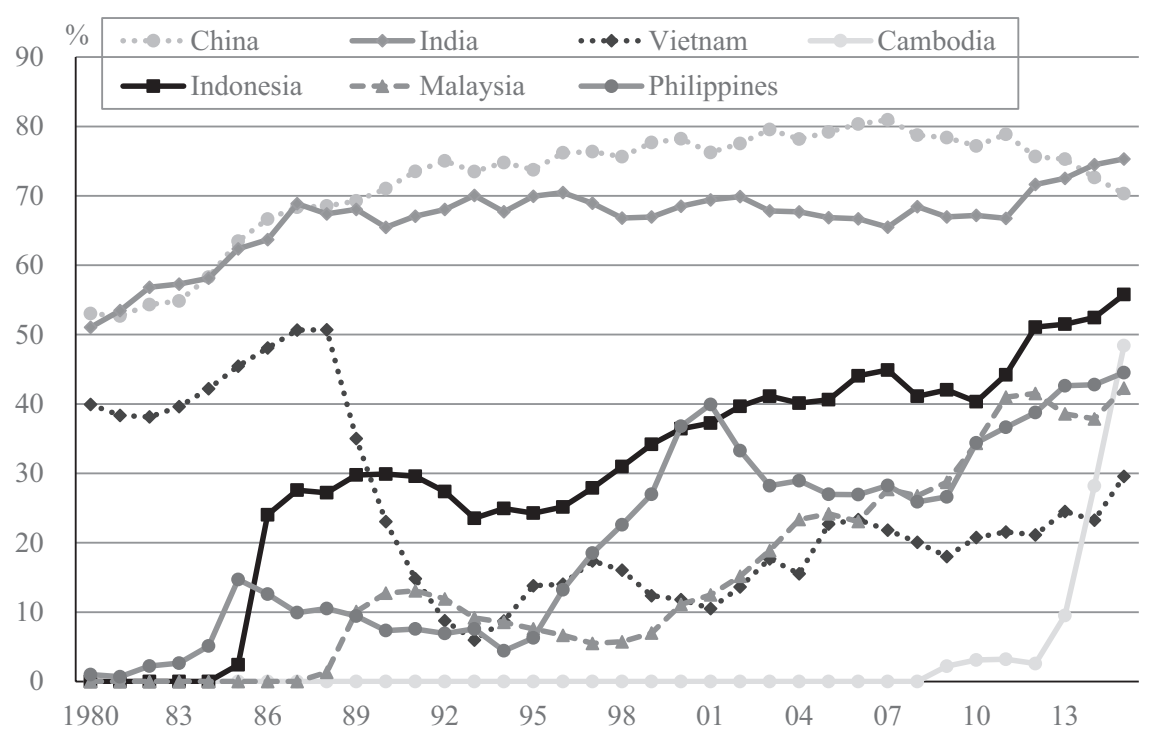

Figure 1.2 Ratio of coal power in power generation in selective Asian countries in 1980-2015.

Source: The author's compilation based on World Bank (2020). 
long-term financing, and Chinese financing institutions became a valuable source for power projects (Vagliasindi, 2013). As a result, these countries have sharply increased coal and lignite imports (Figure 1.3), deteriorating the trade balance.

Foreign finance and investments result in the suspicion that they might generate cross-border carbon relocation or relocation of $\mathrm{CO}_{2}$ emissions to countries with lax commitments in GHG emissions reduction in their NDCs, in addition to ecological and social concerns that have triggered local protests and the suspension or abandonment of coal power projects (Vidal, 2016; Boulle, 2019), as well as hydropower (Fawthrop, 2019). The increase in coal power can intensify a tradeoff with NDCs in host countries, especially those who entrench dependency on China and the institutional lock-in for coal-centered energy systems. It makes these countries incapable of moving the system toward a more sustainable pathway (Mori, 2020).

In response, Ma et al. (2019) argue that decarbonizing the Belt and Road is a means to mitigate adverse environmental impacts of finance and investments. Such de-carbonization requires a mandatory environmental assessment of Chinese investments, applying the green investment principle, transparency regarding the carbon footprint of infrastructure investments for the international society, and building capabilities for green finance in host countries.

Whether such a mitigation measure is sufficient to prevent carbon haven and generate halo effects remain unknown. This investigation became a critical focal point of the argument when President Xi Jinping, at the United

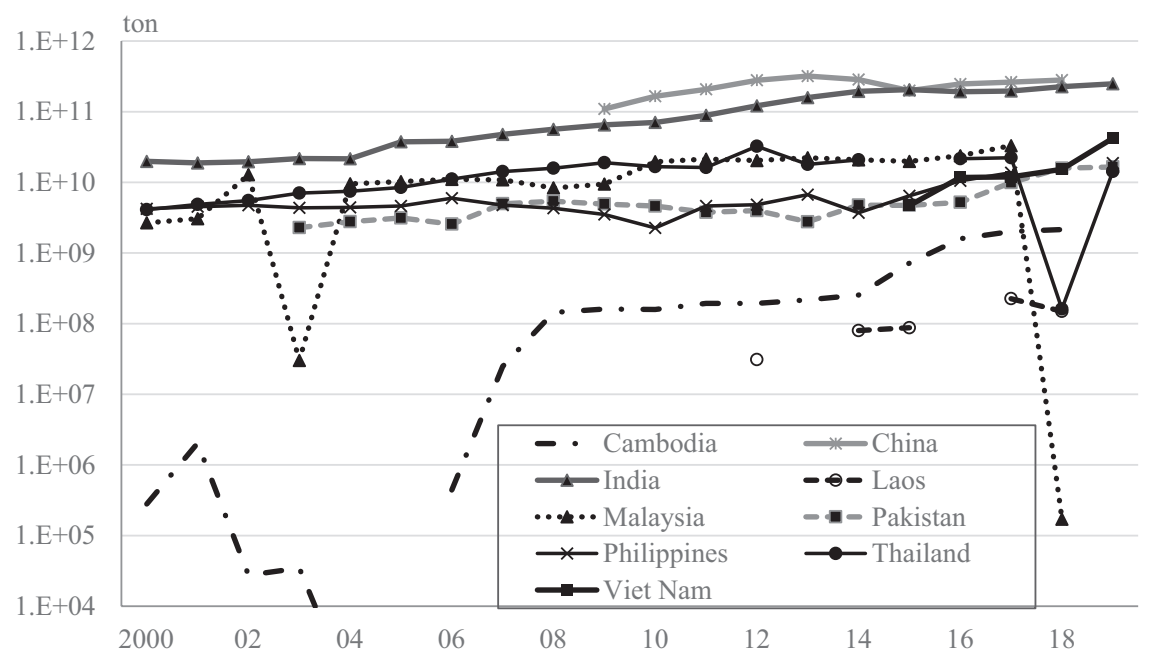

Figure 1.3 Net coal and lignite imports in the selected Asian countries in 2000-2018. Source: The author's compilation based on United Nations Statistics Division (n.a). 
Nations assembly in 2020, pledged carbon neutrality before 2060, without providing details. This ambitious target would result in substantial carbon relocation and creation of carbon havens without a deeper understanding of push and pull factors; mechanisms of and institutions for carbon leakage, relocation, and halos; and evidence-based countermeasures in China and host countries.

\section{Pollution haven and halos}

Increasing the foreign direct investment (FDI) flows accompanied by globalization has raised concerns about their side effects, including those on the environment. On the one hand, a country with lax environmental policies tends to specialize in more pollution- or resource-intensive sectors, becoming a pollution haven of "dirty" industries. To attract foreign investment, developing countries compete to relax or not strictly enforce environmental regulations, resulting in a "race to the bottom" phenomenon in environmental protection called the pollution haven hypothesis. When there are strict environmental regulations, footloose investors of pollution-intensive industries relocate their plants to regions or countries with lax environmental regulation to decrease the costs of protecting the environment, called the industrial flight hypothesis.

On the other hand, the economic structural transformation from manufacturing to services and stringent environmental regulations in investing countries could lead to the relocation of manufacturing industries (Araya, 2005). Alternatively, this transformation provides opportunities for other countries to increase the international competitive edge of their manufacturing sectors. This industrial relocation and the change in comparative advantage might cause negative consequences for the environment.

Theoretically, whether environmental regulations propel pollutionintensive industries to relocate depends on pollutant generation intensity, pollution abatement cost, and relocation cost. Corruption in host countries loosens enforcement of environmental regulations, thus inviting relocation (Candau and Dienesch, 2017). The total amount and intensity of pollutant emissions increase after relocation, and the extent of the increase is positively correlated with the regulation in the home country and negatively correlated with that in the host country (Li and Wang, 2020). This implies that industrial relocation reduces pollution in the home country while increasing it in the host countries.

Empirical studies have supported the pollution haven hypothesis partially at best. Many researchers have pointed out the international relocation of production to countries with weaker environmental regulations in specific periods and regions (Mani and Wheeler, 1998; Zarsky, 1999; Brunnermeier and Levinson, 2004, Ogura and Mori, 2015), and in industries such as resource extraction (Boocock, 2002; Dam and Scholtens, 2012). However, the evidence is weak. Higher pollution abatement costs induced by stringent 
environmental regulations have not substantially affected international trade and FDI flow compared with other factors such as income, trade openness, and the manufacturing share of host countries (Copeland and Taylor, 2003; Cole, 2004). "Dirty" industries do not always invest in dirty technologies and practices (Auer, 2000).

Instead, many empirical studies have found that FDI significantly reduces environmental emissions (Demena and Afesorgbor, 2020). Foreign investors provide more energy-efficient technologies and better management practices, and use cleaner types of energy (Eskeland and Harriso, 2003). Some researchers have further supported pollution halo effects or pollution reduction by demonstrating positive externalities of cleaner technologies and practices (Zarsky, 1999) in countries with higher emissions (Zhu et al., 2016) and in countries with strong governance and quality institutions (Wang and Chen, 2014; Bokpin, 2017; Liu et al., 2017).

However, the halo effect does not always reduce emissions in a host country as a whole. FDI inflow tends to be a tiny portion of domestic capital stock. As long as domestic capital stock is pollution intensive, its net increases lead to increases in production activities and emissions that outweigh the halo effects (Sung et al., 2018). Thus, each nation or firm is reluctant to take unilateral action that undermines competitiveness. The "regulatory chill," or no change in the emission standard, became a rule rather than the exception (Zarsky, 2002).

\section{Carbon leakage and carbon relocation}

Unilateral climate policy, represented by carbon pricing, re-sparks the pollution haven debate in the name of carbon leakage (CL). In particular, the European Union Emissions Trading System (EU ETS) has been criticized for threatening the competitiveness of European industry and generating $\mathrm{CL}$ or increasing GHG emissions in foreign countries. Two options have been argued to address CL: border carbon adjustments and output-based allocation, and auctioning with border adjustment, which is more efficient, at least theoretically (Monjon and Quirion, 2011). However, the European Commission implemented the grandfathering of $\mathrm{CO}_{2}$ allowances in proportion to historical GHG emissions in phases 1 and 2. This drew criticism for rewarding higher emitters, not considering firms' early actions, and exempting high trade exposure industries instead of high carbon-intensive industries from auctions, despite the latter's stronger correlation with CL (Martin et al., 2014). In response, the commission employs product-related GHG emission benchmarks in phase 3 and initiates a carbon border adjustment mechanism, that is, putting a carbon price on imports of certain goods from outside the European Union in the EU Green Deal (European Commission, 2020).

To determine the sectors exposed to a significant climate policyinduced CL or strong CL (Michalek and Schwarze, 2015), and thus be 
grandfathered, the commission provides a formula to calculate the induced carbon costs (European Union, 2015: 63-65). Ex ante modeling analysis has also been conducted, including the computable general equilibrium (CGE) model to assess strong CL at the country level. They suggest a range of $10 \%-40 \%$ of leakage, depending upon the scenario (e.g., a unilateral $0 \% \mathrm{CO}_{2}$ emission reduction by the European Union or Annex I countries in the Kyoto Protocol), scope (fuel combustion or including process emissions), and the extent of sectoral disaggregation (Bednar-Friedl et al., 2012; Caron, 2012).

Ex post empirical studies have demonstrated that EU ETS has induced only a small amount of investment leakage in phases 1 and $2 .^{2}$ Although ETS-regulated German firms on average have increased FDI outside the EU, most of them do not operate in the targeted energy-intensive sectors (Koch and Mana, 2019). Relocation can be averted after phasing out the grandfathering scheme only if the permit price triggers sufficient investments into low-carbon technologies or abatement capital that create a lock-in effect that makes relocation unprofitable (Schmidt and Heitzig, 2014).

This finding implies that firms do not always choose among staying inert with grandfathering, investments in low-carbon technologies for compliance, and complete industrial flight or closure and relocation. They may choose to be multilateral corporations that have industrial plants in many countries or unbundle their closed integral production system to form a global value chain (Ezaki, 2018), to optimize their production in accordance with global demand and local regulations. This implies that foreign investors may selectively relocate carbon-intensive processes to countries with weak environmental regulations, producing intermediate products there and importing them for the last stage of production at their home (Zhang et al., 2017). The partial relocation enables home countries to reduce domestic $\mathrm{CO}_{2}$ emissions through a technological effect and an effect on domestic industrial structure and simultaneously increases embodied emissions through the scale effect (Hao et al., 2020).

Partial relocation of carbon-intensive processes can occur in the electricity sector. Sunk investments, high entry barriers, long operating lifetimes, and complementary capital investments justified public ownership, a vertically integrated supply system, and a monopolistic supply of electricity under the price regulation. Foreign companies were allowed to join only as contractors of turnkey projects funded by foreign donors or host country governments. In the 1990s, pressures for cheap electricity, the lack of funding and insufficient investments, inefficient operation and being susceptible to corruption and bribery due to agency problems, and technological development pushed liberalization of the electricity market, unbundling of the vertically integrated supply system, and privatization of electric utilities or public-private partnership (PPP). This change in the supply regime is expected to mobilize additional sources of funding and financing for infrastructure development, enhance project selection, foster efficiency gains, 
and ensure service delivery (World Bank, 2017). Under the PPP framework, foreign power companies are allowed to join in power projects as independent power producers, and foreign project developers as engineering, procurement, and construction (EPC) contractors. Power companies can invest in switching to gas and RES-E at home, and simultaneously in coal power in foreign countries with weaker regulations when stringent environmental and climate regulations are encountered at home. The selective relocation can be accelerated when cross-border transmission lines are connected between the investing and host countries, and the regulation gap remains intact.

China can not be exempted from the CL risk because it already implemented local carbon emissions trading pilots and a nationwide scheme for the electricity sector. A study identifies 17 four-digit sectors considered at actual risk of CL (Wang et al., 2017).

The above arguments on relocation as firms' responses to stringent carbon-energy policy suggest a specific conceptualization. In this book, we define carbon relocation as the complete and partial relocation or FDI of carbon-intensive industrial plants, industry, and production processes. Carbon relocation constitutes a part of carbon leakage, which is defined as an incremental increase in $\mathrm{CO}_{2}$ emissions in host countries induced by more stringent climate policy in investors' countries and generated by both FDI and international trade.

\section{Carbon halos}

Empirical studies have demonstrated mixed results on the relationship between FDI inflow and $\mathrm{CO}_{2}$ emissions. Some find the halo effect in $\mathrm{CO}_{2}$ emissions, or carbon halo effect in China in 1995-2010 (Zhang and Zhou, 2016), in higher emission countries in the five Association of Southeast Asian Nations (ASEAN) countries of Indonesia, Malaysia, the Philippines, Singapore, and Thailand in 1981-2011 (Zhu et al., 2016), and in the Gulf Cooperation Council countries in 1980-2009 (Al-Mulali and Tang, 2013). Others find opposite results in China in 1980-2012 (Sun et al., 2017); in Malaysia in 1970-2008; in middle-income South and Southeast Asian countries in 1980-2012 (Bahera and Dash, 2017); in 15 developing countries in Asia in 1990-2013 (Hanif et al., 2019); and in BRI countries across South Asia, Southeast Asia, East Asia, and Europe in 1985-2017 (Khan and Bin, 2020).

Because of the similarity in countries and regions and the period of years for analysis, and assuming monotonous increases or inverse-U-shaped relations between per capita income and $\mathrm{CO}_{2}$ emissions, we summarize this research as follows: FDI has generated the carbon halo effect in a limited number of countries, regions, and periods with stringent energy and $\mathrm{CO}_{2}$ emission regulations, and less carbon-intensive sectors at best (Zheng et al., 2010; Lee, 2013; Lau et al., 2014). 
At a micro level, however, greenfield FDI for renewable-energy projects is one of the promising subsectors to generate the carbon halo effect. Such FDI allows both foreign and local companies to engage in the transfer of capital, technology, and expertise through trade and investment (United Nations ESCAP, 2012). India, China, and Indonesia accounted for more than $60 \%$ in the amount of renewable-energy investments in Asia in 2013-2016 (OECD, 2017).

Nonetheless, FDI in the clean energy subsector and exports of clean technology can cause repercussions and backlash in host countries. Grid companies may contest against sharply increased RES-E induced by FDI or imports, resulting in a renewable curtailment. A host country government may impose anti-dumping or restrictive measures to protect domestic manufacturers and power producers if foreign companies are perceived too competitive to push them out of the market. However, anti-dumping or restrictive measures are more likely to trigger a vicious cycle of higher costs, lower demand, and lower deployment of clean technology and energy (Burke et al., 2019). These measures reduce the willingness of the industry to reorient innovation or reorganize to take advantage of FDI and exports to gain a profit (McCarthy, 2016). This eventually retards development of regulations, national capabilities to benefit from the technological spillover effect, and industrial structural change. Worse, these measures may simply motivate foreign manufacturers to intensify their efforts to "tariff jump," offsetting the effectiveness of the measures. This increases uncertainty on whether investment can catch up with future demand for power and climate targets.

Connectivity has the potential to prevent carbon relocation and overcome the repercussions of the FDI-induced increase in RES-E. It enables leastcost dispatch, price stabilization, and improving the economies of scale for new renewable-energy supplies, thus significantly promoting the adoption of renewable energy-sourced electricity (Chang and $\mathrm{Li}, 2015$ ). It is also expected to reduce $\mathrm{CO}_{2}$, sulfur dioxide $\left(\mathrm{SO}_{2}\right)$, and nitrogen oxides ( $\mathrm{NOx}$ ) emissions, and develop clean energy, power, and high-tech industries that will increase GDP (Global Energy Interconnection Development and Cooperation Organization, 2019).

Connectivity can also provide technical benefits, including the reinforcement of system stability, opportunities for sharing ancillary services, and optimization of the energy mix while reducing system vulnerabilities. These benefits will save newly installed capacity for fossil fuel power, reduce fuel import dependencies, and affect resource constraints accordingly (UNESCAP, 2019).

To generate these benefits, United Nations Economic and Social Commission for Asia and the Pacific (UNESCAP) has supported the ASEAN Power Grid and the Trans-ASEAN Gas Pipeline, the two flagship energy connectivity programs in the ASEAN Economic Community "Blueprint 2025." 


\section{Aims and scope}

Against the backdrop, this book defines carbon relocation as a policyinduced complete and partial relocation of carbon-intensive industrial plants and industry and production processes that generate an incremental increase in $\mathrm{CO}_{2}$ emissions in host countries. This book also defines carbon halos as a $\mathrm{CO}_{2}$ emission reduction induced by FDI-brought cleaner technologies and types of energy and better management practices. In this regard, carbon relocation is defined as a specific form of $\mathrm{CL}$, and carbon halos as $\mathrm{CO}_{2}$-focused pollution halos.

With these definitions, this book aims to answer three research questions.

a How has China's carbon-energy policy incentivized outward FDI in coal power and RES-E projects and exports of these technologies?

b How have Chinese outward FDI in and exports of RES-E technologies generated energy transitions in Asian countries, and caused carbon leakage, relocation, and halos?

c Can regional connectivity be a countermeasure to minimize carbon relocation and enhance the carbon halo effect in the context of ChinaAsia energy relations?

To answer these questions, this book employs a mixed method of scenariobased simulation analysis and empirical case studies. For the detailed case studies of host countries, we examine Indonesia, India, and Vietnam. These three countries are rich in easily accessible coal and thus initiated a transition to a coal-centered electricity supply system when they foresaw the depletion of other cheaper sources of energy such as oil and hydropower. They have been the largest recipients of China's overseas FDI in coal power projects in Asia throughout the 2010s, along with Pakistan and Bangladesh, who suddenly emerged in the latter half of the decade (referred to in Chapter 5). In addition, this book analyzes Japan as a case to assess the possible repercussions against the increase in the imports of goods for RES-E from China. Japan was the largest manufacturer of solar PV but lost competitiveness amid the global decline in production cost.

Although this book focuses on Asian countries for empirical case studies, it provides a deeper understanding of the contexts and conditions that generate carbon relocation and halos, and implications that go beyond the context of China-Asia energy relations.

\section{Book overview}

The structure of this book comprises four parts: introduction; China's energy and industrial transformation as a push factor; carbon, leakage, relocation, and halo effects in host countries; and possible countermeasures and future perspectives. 
In Chapter 2, Akihisa Mori develops the complementarities in sociotechnical systems as an analytical framework to investigate how Asian countries have struggled with the energy-climate conundrum under the Paris Agreement, taking Vietnam, Indonesia, India, and Japan as cases. The chapter finds that they have struggled with the challenges of resistance of influential incumbent regime actors, reconciling compelling narratives, and highly unclear and uncertain benefits of the transformation, and these challenges incentivize incumbent regime actors to retard the restructuring of the existing complementarities, especially when they are backed by international actors such as Chinese investors.

The second part, China's energy and industrial transformation comprises three chapters. The first of the three, Chapter 3 by Jiayang Wang and Kiyoshi Fujikawa investigates how a switch in energy mix from coal to wind and solar can be a driving force for China's outward FDI in coal power projects. By employing a scenario input-output analysis, they analyze impacts on economic activity, employment, and $\mathrm{CO}_{2}$ emissions of the shift in energy mix.

In Chapter 4, Nobuhiro Horii investigates how Chinese solar PV manufacturers have enhanced sufficient competitive edge as to dominate the global market. Through a retrospective analysis, this chapter explores how Chinese solar PV manufactures have enhanced technological capabilities to overcome the anti-dumping measures by Europe and the United States, and the phase-out of FiT for solar power in China, resulting in a surge of exports.

In Chapter 5, Akihisa Mori investigates the relations between China's stringent environmental, energy, and climate policy; outward FDI in coal power projects; and carbon relocation.

The third part of the book analyzes how Chinese outward FDI and exports have affected energy transitions, causing carbon relocation and halo effects in the electricity sector in host countries, and generating carbon leakage from China.

Chapters 6 and 7 conduct modeling analyses of the impacts in multiple countries. Chapter 6 by Hikari Ban and Kiyoshi Fujikawa investigates the possible impacts on GDP and $\mathrm{CO}_{2}$ emissions of China's outward FDI in coal power projects in Indonesia, Vietnam, India, and five Central Asian countries of Kazakhstan, Kyrgyzstan, Tajikistan, Turkmenistan, and Uzbekistan. To make the simulation analysis be more realistic, they employ an energy-environmental version of the Global Trade Analysis Project (GTAP-E) model, a global CGE model, and use actual China's development finance in coal power projects compiled by the China's Global Power Database (Gallagher et al., 2019).

In Chapter 7, Yasuhiro Ogura explores possible carbon halo effects through imports of wind and solar PV technologies. The chapter employs matching econometrics to analyze the correlation between renewableenergy policy and the international trade of these technologies, gaining insights on enabling factors of market deployment of these technologies. 
Chapters 8-10 adopt a case study of one country as a methodology to explore the dynamics of Chinese outward investments in power projects, exports of wind and solar PV technologies, and policy responses in Indonesia, India, and Japan.

Chapter 8 by Maxensius Tri Sambodo investigates the role of Chinese investments, finance, and contracts in coal power projects in and their exports of RES-E technologies to Indonesia from the energy security perspective.

Nandakumar Janardhanan in Chapter 9 evaluates the opportunities and obstacles of China's role in energy transition in India. Although India set ambitious renewable-energy targets, it suffers from the lack of an internationally competitive domestic RSE-E manufacturers and thus increases dependency on imports from China. Based on a conceptual framework of bilateral energy cooperation, this chapter explores conditions for Chinese large exports of RES-E technologies to generate carbon halo effect.

In Chapter 10, Takashi Hattori and Yi-chun Chen investigate Japan as a case of a host country. Japanese solar PV manufacturers used to be the world's leading ones but lost competition against Chinese ones, resulting in a massive deployment of Chinese solar PV modules in Japanese market. This chapter explores what has brought about this result, and how the losing competitive edge of Japanese manufacturers affects carbon-energy policies in Japan.

In Chapter 11, Tuyet Le Vo and Yiyi Ju investigate how carbon relocation and halo effects in the electricity sector generated by Chinese outward FDI affect the increasing trend of $\mathrm{CL}$ in terms of embodied $\mathrm{CO}_{2}$ emissions in China. They take Vietnam, Indonesia, India, and Japan as cases and employ single-region and multi-region input-output tables to estimate embodied $\mathrm{CO}_{2}$ emissions of the whole sector as well as by industrial sectors.

The final part explores countermeasures that host countries can take to mitigate carbon relocation and increase carbon halo effects of Chinese investments and export, and enhance energy security to satisfy growing demand, supply electricity around the country at an affordable price at the same time.

In Chapter 12, Budy P. Resosudarmo and Yuventus Effendi investigate if Asian regional electricity market integration can generate the above positive effects, with special focus on macroeconomic and $\mathrm{CO}_{2}$ emissions. They employ the inter-regional constrained fixed price multiplier (CFPM) method and an inter-regional social accounting matrix (IRSAM)-based microsimulation, and a carbon emission model to make a comparative analysis of the socioeconomic and environmental impacts of regional electricity market integration between ASEAN and Asian Pacific Region covering China, South Korea, Japan, and Australia.

Chapter 13 summarizes the main findings presented in each chapter of this book, discusses implications for carbon leakage, relocation, and halo effects of Chinese outward FDI and exports of RES-E technologies, and suggests that the remaining challenges are topics for further research. 


\section{Notes}

1 Chapter 5 presents the list of companies in each category.

2 Energy-environment-economy (E3) simulation model also shows that environmental tax reform in EU member states in 1985-2012 induces investment leakage by only $3 \%$ at best. This occurs because the reform induces innovation and reduces the energy intensity of the associated industries (Barker et al., 2007).

\section{References}

Al-mulali, U., C.F. Tang, 2013. Investigating the validity of pollution haven hypothesis in the gulf cooperation council (GCC) countries, Energy Policy 60, 813-819, https://doi.org/10.1016/j.enpol.2013.05.055.

Auer, M., 2000. Pollution havens and industrial flight: Weighing the evidence. In: Bonser, CF (eds.) Security, Trade, and Environmental Policy, Springer, Boston, MA. https://doi.org/10.1007/978-1-4615-4399-2_30.

Araya, M., 2005. FDI and the environment: What empirical evidence does- and does not-tell us. In: Zarsky, L. (ed.) International Investment for Sustainable Development: Balancing Rights and Rewards. Earthscan, London, 530-548.

Bahera, S.R., D.P. Dash, 2017. The effect of urbanization, energy consumption, and foreign direct investment on the carbon dioxide emission in the SSEA (South and Southeast Asian) region, Renew. Sust. Energ. Rev. 70, 96-106, https://doi. org/10.1016/j.rser.2016.11.201.

Barker, T., S. Junankar, H. Pollitt, P. Summerton, 2007. Carbon leakage from unilateral Environmental Tax Reforms in Europe, 1995-2005, Energy Policy 35 (12), 6281-6292, https://doi.org/10.1016/j.enpol.2007.06.021.

Beardsworth, J.J. Jr., J.A. Schmidt, 2014. Resource financed infrastructure: Origins and issues, In: Halland, H., J. Beardsworth, B. Land, and J. Schmidt, Resource Financed Infrastructure, A Discussion on a New Form of Infrastructure Financing, The World Bank: Washington DC, 11-68, http://dx.doi.org/10.1596/978-14648-0239-3.

Bednar-Friedl, B., T. Schinko, K.W. Steininger, 2012. The relevance of process emissions for carbon leakage: A comparison of unilateral climate policy options with and without border carbon adjustment, Energy Econ. 34, S168-S180, https://doi. org/10.1016/j.eneco.2012.08.038.

Bokpin, G.A., 2017. Foreign direct investment and environmental sustainability in Africa: The role of institutions and governance, Res. Int. Bus. Finance 39, Part A, 239-247, https://doi.org/10.1016/j.ribaf.2016.07.038.

Boocock, C.N., 2002. Environmental impacts of foreign direct investment in the mining sector in Sub-Saharan Africa. In: OECD (ed.) Foreign Direct Investment and the Environment: Lessons from the Mining Sector, OECD, Paris, 19-53, https:// doi.org/10.1787/9789264199026-en.

Boulle, M., 2019. The hazy rise of coal in Kenya: The actors, interests, and discursive contradictions shaping Kenya's electricity future, Energy Res. Soc. Sci. 56, 101205, https://doi.org/10.1016/j.erss.2019.05.015.

Burke, P., J. Widnyana, Z. Anjum, E. Aisbett, B. Resosudarmo, K.G.H. Baldwin, 2019. Overcoming barriers to solar and wind energy adoption in two Asia giants: India and Indonesia. Energy Policy 132, 1216-1228, https://doi.org/10.1016/j. enpol.2019.05.055. 
Brunnermeier, S.B., A. Levinson, 2004. Examining the evidence on environmental regulations and industry location, J Environ Dev. 13 (1), 6-41, https://doi. org/10.1177/1070496503256500.

Caron, J., 2012. Estimating carbon leakage and the efficiency of border adjustments in general equilibrium-Does sectoral aggregation matter? Energy Econ. 34, S111-S126, https://doi.org/10.1016/j.eneco.2012.08.015.

Candau, F., E. Dienesch, 2017. Pollution haven and corruption paradise, J Environ Econ Manage. 85, 171-192, http://dx.doi.org/10.1016/j.jeem.2017.05.005.

Chang, Y., Y. Li, 2015. Renewable energy and policy options in an integrated ASEAN electricity market: Quantitative assessments and policy implications, Energy Policy 85, 39-49, https://doi.org/10.1016/j.enpol.2015.05.011.

Chen, S., 2013. Energy, Environment and Economic Transformation in China, Oxon: Routledge.

Cole, M.A., 2004. Trade, the pollution haven hypothesis and the environmental Kuznets curve: Examining the linkages, Ecol. Econ. 48, 71-81, https://doi. org/10.1016/j.ecolecon.2003.09.007.

Copeland, B.R., S.M. Taylor, 2003. Trade and the Environment: Theory and Evidence, Princeton University Press, Princeton and Oxford.

Dam, L., B. Scholtens, 2012. The curse of the haven: The impact of multinational enterprise on environmental regulation, Ecol. Econ. 78, 148-156, https://doi. org/10.1016/j.ecolecon.2012.04.011.

de la Tour, A., M. Glachant, Y. Ménière, 2011. Innovation and international technology transfer: The case of the Chinese photovoltaic industry, Energy Policy 39: 761-770, https://doi.org/10.1016/j.enpol.2010.10.050.

Demena, B.A., S.K. Afesorgbor, 2020. The effect of FDI on environmental emissions: Evidence from a meta-analysis, Energy Policy 138, 111192, https://doi. org/10.1016/j.enpol.2019.111192.

European Commission, 2020. EU Green Deal (carbon border adjustment mechanism), https://ec.europa.eu/info/law/better-regulation/have-your-say/initiatives/12228-Carbon-Border-Adjustment-Mechanism/, [accessed 22 September 2020].

European Union, 2015. EU ETS Handbook, https://ec.europa.eu/clima/sites/clima/ files/docs/ets_handbook_en.pdf/, [accessed 22 September 2020].

Eskeland, G.S., A.E. Harrison, 2003. Moving to greener pastures? Multinationals and the pollution haven hypothesis, J. Dev. Econ 70 (1), 1-23, https://doi. org/10.1016/S0304-3878(02)00084-6.

Ezaki, Y., 2018. Deciphering the Current Status on Infrastructure Exports of Japanese Companies, Bunshindo, Tokyo (in Japanese).

Fawthrop, T., 2019. Myanmar's Myitsone Dam Dilemma: As the unpopular project sits in limbo, the government has to choose between upsetting China and enraging its own people, The Diplomat (11 March 2019), https://thediplomat.com/2019/03/ myanmars-myitsone-dam-dilemma/, [accessed 4 September 2020].

Gallagher, K.P., R. Kamal, J. Jin, Y. Chen, X. Ma, 2018. Energizing development finance? The benefits and risks of China's development finance in the global energy sector, Energy Policy 122, 313-321, https://doi.org/10.1016/j.enpol. 2018.06.009.

Gallagher, K.P., Z. Li, X. Chen, X. Ma, 2019. China's Global Power Database, Global Development Policy Center, Boston University, https://www.bu.edu/cgp/, [accessed 25 December 2020]. 
Global Energy Interconnection Development and Cooperation Organization, 2019. Research and Outlook on Asian Energy Interconnection, China Electric Power Press, Beijing.

Hanif, I., S.M.F. Raza, P. Gago-de-Santos, Q. Abbas, 2019. Fossil fuels, foreign direct investment, and economic growth have triggered $\mathrm{CO}_{2}$ emissions in emerging Asian economies: Some empirical evidence, Energy 171, 493-501, https://doi. org/10.1016/j.energy.2019.01.011.

Hao Y., Y. Guo, Y. Guo, H. Wu, S. Ren, 2020. Does outward foreign direct investment (OFDI) affect the home country's environmental quality? The case of China, Struct. Chang. Econ. 52, 109-119, https://doi.org/10.1016/j.strueco. 2019.08.012.

Hayashi, K., 2006. Conditions for high-performer in international oil and gas upstream industry: A CERA proposal for increasing international competitiveness of Japanese firms, Oil and Gas Review 40 (3), 33-41 (in Japanese).

Hervé-Mignucci, M., X. Wang, 2015. Slowing the growth of coal power outside China: The role of Chinese Finance, A CPI Report, Climate Policy Initiative, https:/climatepolicyinitiative.org/wp-content/uploads/2015/11/Slowing-theGrowth-of-Coal-Power-Outside-China.pdf/, [accessed 20 April 2020].

Horii, N., 2014. The wind turbine industry: the role of policy and markets in the catch-up process. In: Watanabe, M. (ed.) The Disintegration of Production: Firm Strategy and Industrial Development in China, Edward Elgar, Cheltenham, 127-148.

Khan, Y., Q. Bin, 2020. The environmental Kuznets curve for carbon dioxide emissions and trade on belt and road initiative countries: A spatial panel data approach, Singap. Econ. Rev. 65, 1099-1126, https://doi.org/10.1142/S02175908 19500255.

Koch, N., H.B. Mama, 2019. Does the EU Emissions Trading System induce investment leakage? Evidence from German multinational firms, Energy Econ. 81, 479-492, https://doi.org/10.1016/j.eneco.2019.04.018.

Koehn, P.H., 2016. China Confronts Climate Change: A Bottom-up Perspective, Routledge, Oxon.

Lau, L.S., C.K. Choong, Y.K. Eng, 2014. Investigation of the environmental Kuznets curve for carbon emissions in Malaysia: Do foreign direct investment and trade matter? Energy Policy 68, 490-497, https://doi.org/10.1016/j.enpol. 2014.01.002.

Lechner, A.M., J.R. Owen, A. Tritto, A.H. Hoong, C. Teo, C.M. Tan, A. CamposArceiz, 2020. China's belt and road: An environmental disaster for Southeast Asia? South China Morning Post (4 January 2020), https://www.scmp.com/news/ hong-kong/politics/article/3044453/digital-silk-road-inspired-chinas-belt-androad-initiative/, [accessed 27 January 2020].

Lee, J.W., 2013. The contribution of foreign direct investment to clean energy use, carbon emissions and economic growth, Energy Policy 55, 483-489, https://doi. org/10.1016/j.enpol.2012.12.039.

Li, M., Q. Wang, 2020. Does industrial relocation alleviate environmental pollution? A mathematical economics analysis, Environ Dev Sustain. 22, 4673-4698, https://doi.org/10.1007/s10668-019-00403-7.

Liu, Y., Y. Hao, Y. Gao, 2017. The environmental consequences of domestic and foreign investment: Evidence from China, Energy Policy 108, 271-280, https://doi. org/10.1016/j.enpol.2017.05.055. 
Ma, J., S. Zadek, T. Sun, S. Zhu, L. Cheng, J. Els, T. Nielsen, D. Ren, I. Granoff, T. Stumhöfer, 2019. Decarbonizing the Belt and Road: A Green Finance Roadmap, https://www.vivideconomics.com/casestudy/decarbonizing-the-belt-and-roadinitiative-a-green-finance-roadmap/, [accessed 19 September 2020].

Mani, M., D. Wheeler, 1998. In search of pollution havens? Dirty Industry in the World Economy, 1960 to 1995, J Environ Dev. 7 (3), 215-247, https://doi. org/10.1177/107049659800700302.

Martin, R., M., Muûls, L.B. de Preuxa, U.J. Wagnerd, 2014. On the empirical content of carbon leakage criteria in the EU Emissions Trading Scheme, Ecol. Econ. 105, 78-88, https://doi.org/10.1016/j.ecolecon.2014.05.010.

McCarthy, K.J., 2016. On the influence of the European trade barrier on the Chinese PV industry: Is the solution to the solar-dispute "successful"? Energy Policy 99, 154-157, https://doi.org/10.1016/j.enpol.2016.09.055.

Michalek, G., R. Schwarze, 2015. Carbon leakage: Pollution, trade or politics? Environ Dev Sustain. 17, 1471-1492, https://doi.org/10.1007/s10668-014-9616-8.

Monjon, S., P. Quirion, 2011. Addressing leakage in the EU ETS: Border adjustment or output-based allocation? Ecol. Econ. 70, 1957-1971, https://doi.org/10.1016/ j.ecolecon.2011.04.020.

Mori, A., 2018. Sociotechnical and political economy perspectives in the Chinese energy transition, Energy Res. Soc. Sci. 35, 29-36, https://doi.org/10.1016/ j.erss.2017.10.04.

Mori, A., 2020. Foreign actors, faster transitions? Co-evolution of complementarities, perspectives and sociotechnical systems in the case of Indonesia's electricity supply system, Energy Res. Soc. Sci. 69, 101594, https://doi.org/10.1016/ j.erss.2020.101594.

Mori, A., M. Takehara, 2018. Revisiting China's climate policy: The climateenergy conundrum point of view. In: Mori, A. (ed.) China's Climate-Energy Policy: Domestic and International Impacts, Routledge, 33-51, https://doi. org/10.4324/9781351037587-3.

National Development and Reform Commission (NDRC), 2007. China's National Climate Change Programme.

National Development and Reform Commission (NDRC), 2015. Enhanced actions on climate change: China's intended nationally determined contributions, https://www4.unfccc.int/sites/ndestaging/PublishedDocuments/China\%20First/ China $\% 27 \mathrm{~s} \% 20$ First $\% 20$ NDC\%20Submission.pdf/, [accessed 17 September 2020].

OECD, 2017. Economic Outlook for Southeast Asia, China and India 2017: Addressing Energy Challenges, OECD Publishing, Paris, http://dx.doi.org/10.1787/saeo2017-en/, [accessed 10 October 2017].

Ogura, Y., A. Mori, 2015. Changes in trade and economic structure during the past 25 years, Have green growth, low-carbon strategies made a significant impact in Northeast Asia? In: Yoshida, F., A. Mori (eds.) Green Growth and Low Carbon Development in East Asia, Routledge, Abingdon, 77-96.

Schmidt, R.C., J. Heitzig, 2014. Carbon leakage: Grandfathering as an incentive device to avert firm relocation, J Environ Econ Manage. 67 (2), 209-223, https:// doi.org/10.1016/j.jeem.2013.12.004. 
Sun, C., F. Zhang, M. Xu, 2017. Investigation of pollution haven hypothesis for China: An ARDL approach with breakpoint unit root tests, J. Clean. Prod. 161, 153-164, http://dx.doi.org/10.1016/j.jclepro.2017.05.119.

Sung, B., W.Y. Song, S.D. Park, 2018. How foreign direct investment affects $\mathrm{CO}_{2}$ emission levels in the Chinese manufacturing industry: Evidence from panel data, Econ Syst. 42, 320-331, https://doi.org/10.1016/j.ecosys.2017.06.002.

United Nations Environment Programme (UNEP), 2019. Emissions Gap Report 2019, UNEP, Nairobi, http://www.unenvironment.org/emissionsgap/, [accessed 5 October 2020].

United Nations ESCAP, 2012. Decentralized energy system, Fact Sheet, United Nations Economic and Social Commission for Asia and the Pacific, http://www. unescap.org/sites/default/files/14.\%20FS-Decentralized-energy-system.pdf/, [accessed 23 September 2020].

United Nations ESCAP, 2019. Electricity connectivity roadmap for Asia and the Pacific: Strategies towards interconnecting the region's grids, https://www. unescap.org/sites/default/files/publications/Final-Publication_Electricity_ Connectivity_Roadmap.pdf/, [accessed 1 October 2020].

United Nations Framework for Climate Change Convention (UNFCCC), 2015. The Paris Agreement, https://unfccc.int/process-and-meetings/the-paris-agreement/ the-paris-agreement/, [accessed 19 August 2020].

United Nations Framework for Climate Change Convention (UNFCCC), 2020. NDC Registry, https://www4.unfccc.int/sites/ndcstaging/Pages/Home.aspx/, [accessed 17 September 2020].

United Nations Statistics Division, n.a. UN Comtrade, https://comtrade.un.org/ data/, [accessed 2 October 2020].

Vagliasindi, M., 2013. Revisiting Public-Private Partnerships in the Power Sector, World Bank, Washington, DC, https://ppp.worldbank.org/public-privatepartnership/sites/ppp.worldbank.org/files/documents/WB\%20Study\%202013. pdf/, [accessed 1 October 2020].

Vidal, J., 2016. Bangladesh coal plant protests continue after demonstrators killed, The Guardian (6 April 2016), http://www.theguardian.com/environment/2016/ apr/06/bangladesh-coal-plant-protests-continue-after-demonstrators-killed/, [accessed 19 August 2020].

Wang, D.T., W.Y. Chen, 2014. Foreign direct investment, institutional development, and environmental externalities: Evidence from China, J. Environ. Manag. 135, 81-90, https://doi.org/10.1016/j.jenvman.2014.01.013.

Wang, X., F. Teng, S. Zhou, B. Cai, 2017. Identifying the industrial sectors at risk of carbon leakage in China, Clim. Policy 17 (4), 443-457, https://doi.org/10.1080/146 93062.2015.1104497.

World Bank. 2017. Public-private partnerships: Reference guide version 3. World Bank, Washington, DC, https://openknowledge.worldbank.org/handle/ 10986/29052/, [accessed 23 September 2020].

World Bank, 2020. DataBank: World development indicators, https://databank. worldbank.org/source/world-development-indicators\#/, [accessed 24 September 2020]. 


\section{Akihisa Mori}

Zarsky, L., 1999. Havens, halos and spaghetti: Untangling the evidence about foreign direct investment and the environment. In: OECD (ed.) Foreign Direct Investment and the Environment, OECD, Paris, 47-74.

Zarsky, L., 2002. Stuck in the mud? National states, globalization and the environment. In: Gallagher, K.P., J. Werksman (eds.) Earthscan Reader on International Trade and Sustainable Development, Earthscan, 45-76.

Zhang, C., X. Zhou, 2016, Does foreign direct investment lead to lower $\mathrm{CO}_{2}$ emissions? Evidence from a regional analysis in China, Renew Sust Eenerg Rev. 58, 943-951, https://doi.org/10.1016/j.rser.2015.12.226.

Zhang, Z., K. Zhu, G.J.D. Hewings, 2017. A multi-regional input-output analysis of the pollution haven hypothesis from the perspective of global production fragmentation, Energy Econ. 64, 13-23, http://dx.doi.org/10.1016/j.eneco.2017.03.007.

Zheng S., M.E. Kahn, H. Liu, 2010. Towards a system of open cities in China: Home prices, FDI flows and air quality in 35 major cities, Reg. Sci. Urban. Econ. 40 (1), 1-10, https://doi.org/10.1016/j.regsciurbeco.2009.10.003.

Zhu, H., L. Duan, Y. Guo, K. Yu, 2016. The effects of FDI, economic growth and energy consumption on carbon emissions in ASEAN-5: Evidence from panel quantile regression, Econ. Model. 58, 237-248, https://doi.org/10.1016/j. econmod.2016.05.003. 